оценить его изменения, повысить точность прогнозов ледовых условий, разработать критерии оценки рисков и минимизировать их влияние на безопасность зимнего плавания судов по Дальневосточному транспортному коридору.

$$
* * *
$$

1. Якунин Л. П., Плотников В. В. Проект «Моря». Гидрология и гидрохимия морей // - Том Х: Берингово море. - Выпуск 1: Гидрометеорологические условия. - СПб.: Гидрометеоиздат, 1999. С. 246-279.

2. Думанская И. О. Ледовые условия морей азиатской части России. - М., Обнинск: ИГ-СОЦИН, 2017. - $640 \mathrm{c.}$.

3. Вакульская Н. М., Плотников В. В. Оценки параметров состояния ледяного покрова Берингова моря // Криосфера Земли, 2014, т. XVIII, № 1, с. 92-100

4. Романюк В. А, Минервин И. Г., Пищальник В. М. Восстановление ряда ледовитости Охотского моря с 1882 по 2015 г. // Физика геосфер: 1Х-й Всероссийский симпозиум, 31 августа - 4 сентября 2015 г., г. Владивосток, Россия: мат. докл. / Учреждение Российской академии наук Тихоокеанский океанологический институт им. В. И. Ильичева Дальневосточного отделения РАН. - Владивосток: Дальнаука, 2015 б. - С. 194-198.

5. Пищальник В. М., Дорофеева Д. В., Минервин И. Г., Шумилов И. В., Никулина И. В. Межгодовая динамика аномалий ледовитости Татарского пролива с 1882 по 2018 г. // Известия ТИНРО, 2019 T. 196. - C. 1-9

6. Пищальник В. М., Романюк В. А., Минервин И. Г., Батухтина А. С. Анализ динамики аномалий ледовитости Охотского моря в период с 1882 по 2015 г. // Известия ТИНРО, 2016. - Т. 185. - С. 228-239.

7. Якунин Л. П. Атлас границ преобладающего однолетнего льда дальневосточных морей России. Препринт. Владивосток: ТОИ ДВО РАН, 1997. - 32 с.

8. Walsh, J.E., Chapman W.L, Fetterer F. and Stewart S. Gridded Monthly Sea Ice Extent and Concentration, 1850 Onward, Version 2. Boulder, Colorado USA 2019. NSIDC: National Snow and Ice Data Center. Doi: https://dx.doi.org/10.7265/jj4s-tq79.

9. Минервин И. Г., Романюк В. А., Пищальник В. М., Трусков П. А. Районирование ледяного покрова Охотского и Японского морей // Вестник Российской Академии Наук, 2015 а. - Т. 85. - № 1. - C. 24-32.

10. Романюк В. А. Ледовый режим Охотского моря в условиях глобальной тенденции увеличения температуры воздуха: дисс. канд. геогр. наук // ТОИ ДВО РАН. - Владивосток, 2019. - 125 с.

\title{
Оськина М.А. \\ Разработка геоинформационной системы «Формирование гидрохимического облика Камского водохранилища»
}

doi: $10.18411 / s r-10-04-2021-91$

В настоящее время географические информационные системы (ГИС) являются наиболее эффективным инструментом познания постоянно изменяющейся географической среды. Они находят применение в самых разных областях человеческой деятельности - там, где идет работа с данными, имеющими географическую привязку, где нужно показать или оценить взаимное расположение объектов на местности, где решение вопроса требует учета географического распределения одного или нескольких факторов. ГИСы в настоящее время всё чаще применяются в гидрологии, как за рубежом, так и в России. Например, Федеральное агентство водных ресурсов пользуется специально созданной ГИС для внутреннего пользования, а существующая ГИС водных ресурсов Швейцарии находится в свободном интерактивном доступе. Широко применяются локальные ГИС, такие как «Пространственное моделирование загрязнения водных объектов», разработанное в Санкт-Петербурге. В Пермском крае разработана локальная ГИС «Воткинского водохранилища», существует ГИС «Территориальная Система Экологического Мониторинга (ТСЭМ) Пермского края». Эти системы предназначены для создания 
цифровых карт, демонстрирующих распределение определенных свойств окружающей среды и объектов на местности, для выявления закономерностей и взаимоотношений объектов в окружающем мире, а также для исследования изменений, произошедших на изучаемой территории за определенный период времени.

В условиях значительной остроты водных проблем и в Пермском крае, большую актуальность приобрел вопрос оперативного анализа постоянно обновляющегося облика водных объектов, в частности Камского водохранилища. Ввода и пополнения, хранения больших объёмов информации, характеризующей изменения гидрохимического состава вод, а так же визуализации данных по объекту, для последующей оперативной работы и анализа.

Это становится возможным при использовании метода геоинформационных систем.

Целью работы являлась разработка технического средства (проекта ГИС), для расширения возможностей изучения формирования гидрохимического облика Камского водохранилища.

Ядро ГИС составляют два компонента - данные и программное обеспечение, ответственное за хранение этих данных и за их обработку.

Данные - это важнейший компонент ГИС, описывающий изучаемую территорию. Географические информационные системы работают с данными двух основных типов: пространственные (географические) и описательные (атрибутивные, табличные) данные о географических объектах, состоящие из наборов чисел, текстов, изображений и т. п.

Географические информационные системы не хранят карты в общепринятом смысле, но имеют дело с данными, организованными в базу данных (БД), из которых с помощью программного инструментария, являющегося частью ГИС, можно создать картографическое представление, оптимальное для каждой конкретной задачи.

Представить структуру ГИС «Формирование гидрохимического облика Камского водохранилища» можно в виде блок-схемы (рис. 1), где выделены этапы её формирования и используемая информация.

Блок-схема структуры ГИС «Формирование гидрохимического режима Камского водохранилища»

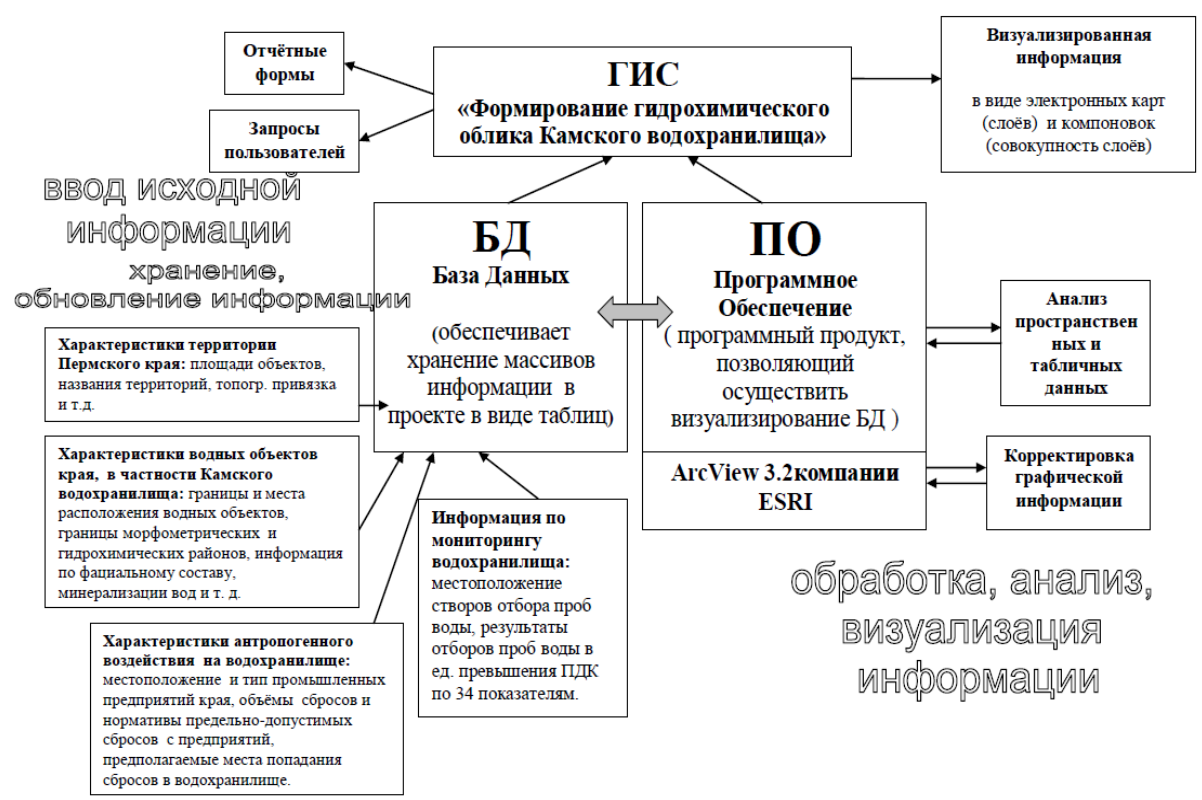


Для создания системы был использован программный продукт компании ESRI ArcView версии 3.2. База Данных проекта была сформирована при помощи собора в единую систему результатов многих исследований прошлых лет (2006-2010 гг.), касающихся гидрохимии водохранилища. А так же проект был дополнен информацией результатов гидрохимического мониторинга, проводимого на водоёме в 2009-2010г. Так же в проект была внесена имеющаяся информацию о самом водохранилище, а так же базовая информацию по территории Пермского края. Эти данные позволили построить на их основе карты (рис. 2), анализировать динамику изменений. Помимо прочей базовой информации по гидрохимии объекта, необходимо было внести в проект, полученные при полевых работах с участием автора, доступные результаты отборов проб воды за 2008г.

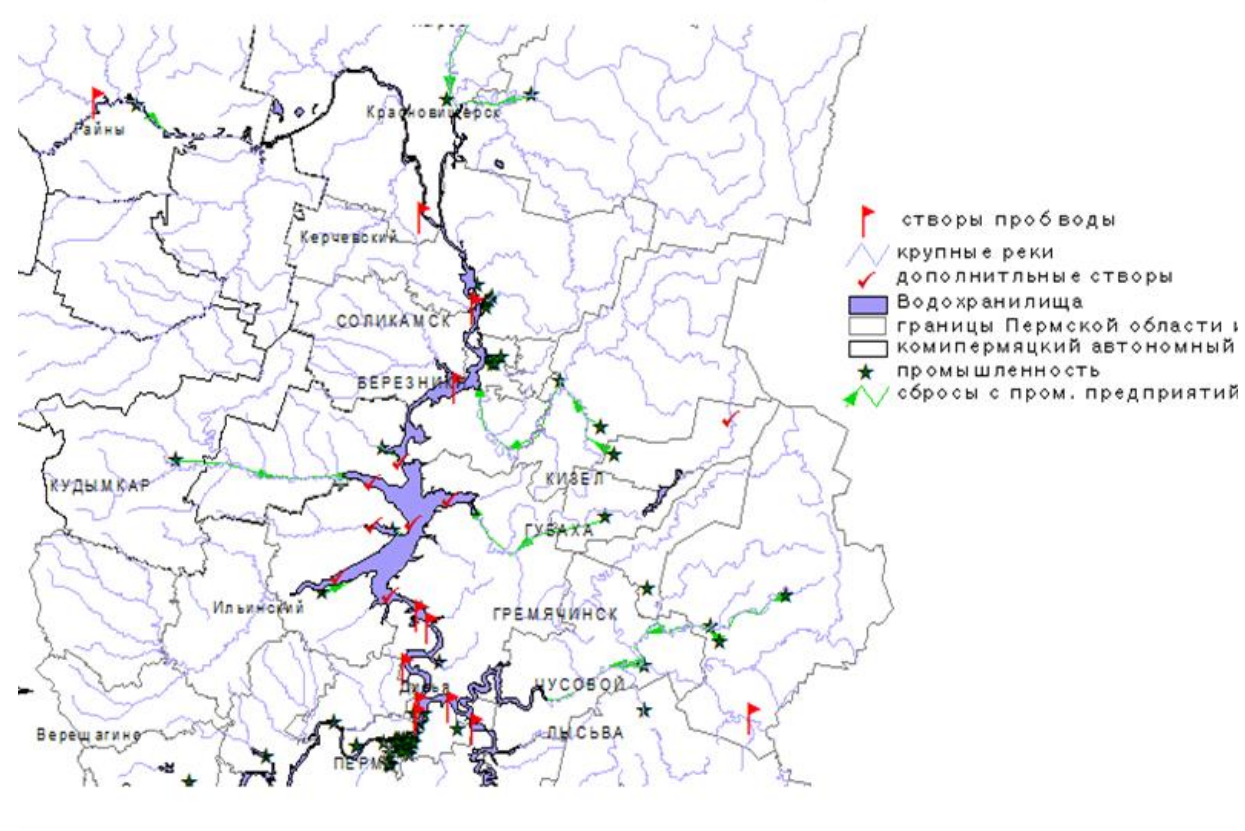

В процессе работы была создана геоинформационная система, которая позволила наглядно представить сложившуюся на территории Пермского края ситуацию, обработать исходные данные и вывести на карту результаты исследования в виде соответствующих слоёв.

Данная ГИС представляет собой проект, состоящий из совокупности тем. Основными темами проекта являются: границы Пермской области и Коми-пермяцкого округа, города, малые и крупные реки, водохранилища, промышленные предприятия (51 шт), предполагаемые места попадания стоков в водохранилище, гидрохимические створы, значения ПДК $\mathrm{plx}$. Кроме того, в проект были внесены результаты исследований по данной теме прошлых лет: фациальный состав вод водохранилища (зимний и летний сезон), минерализация вод водохранилища (зимний и летний сезон), так же обозначены границы морфометрических районов Камского водохранилища.

Атрибутивные данные слоёв содержатся в табличном формате в проекте. Таблица атрибутов не является стационарной в них можно добавлять данные и тем самым расширять возможности использования данной геоинформационной системы. Как предприятия, так и исследователи, работающее с данными такого типа, могут приспособить ее для своих целей.

После внесения в проект всей имеющейся тематической информации автор пришёл к следующим выводам.

Количество створов нельзя считать достаточным для корректного мониторинга гидрохимического состояния Камского водохранилища. Для повышения 
эффективности работы сети мониторинга предложено расширить сеть наблюдения, добавив 8 новых створов, из них 7 на самом водохранилище, и 1 по межсубъектовой реке. В ГИС проекте создан соответствующий слой «дополнительные створы» с примерным расположением предполагаемых створов.

Для более корректной оценки антропогенного воздействия на водохранилище в работе проводился анализ антропогенной нагрузки на водные объекты, создаваемой сточными водами крупнейших предприятий Пермского края. Наибольшая нагрузка приходится на Красновишерский, Добрянский, Пермский район и г.Пермь, чрезвычайно высоко антропогенное влияние и в г.Соликамск и г. Березники. По результатам работы с созданной ГИС, было замечено несоответствие летнего фациального состава вод водохранилища, фациальному составу рек, несущих воды в водохранилище. В трёх заливах водохранилища последний ион - это хлор. Такое поступления хлора в водоем является результатом промышленного загрязнения.

Так же в процессе работы автор попытался оценить современный фациальный состав вод Камского водохранилища. Интересным является тот факт, что гидрохимические фации водохранилища на момент проведения исследования сменились либо на гидрокарбонатно-сульфатно-кальциевую, либо, в меньшей степени, на гидрокорбонатно-кальциево-хлоридную. В проекте были созданы специальные слои, отображающие данную обстановку.

С помощью геоинформационной системы «Формирование гидрохимического облика Камского водохранилища» могут быть решены следующие задачи:

1. Созданный проект ГИС при последующей доработке может помочь оценивать качество водных объектов, создать районирование акватории водохранилища с учётом техногенной нагрузки, анализировать деятельность пользователей водных ресурсов.

2. Ранжировать водопользователей по степени воздействия на водный объект, рассчитывать экологическую нагрузку. Что, в свою очередь, будет способствовать формированию рекомендаций по организации рационального использования водных ресурсов.

$$
\text { *** }
$$

1. Авакян А.Б., Салтанкин В.П. Вопросы акваториального комплексного районирования и планировки на примере волжского бассейна// Всес. Научн. Конф. По проблемам комплексного использования Волги. Пермь, 1975г.

2. Актуальные вопросы гидрологии и гидрохимии Камского водохранилища, под ред. Китаева А.Б., Пермский ун-т, 2004г.

3. Алексеев В.В., Куракина Н.И., Орлова Н.В., Геоинформационная система мониторинга водных объектов и нормирования экологической нагрузки Санкт-Петербургский государственный электротехнический университет «ЛЭТИ», Санкт-Петербург, www. dataplus.ru

4. Растоскуев В.В. , Шалина Е.В., Геоинформационные технологии при решении задач экологической безопасности: Учеб.-метод. - СПб, 2006. - 256 с.

5. Геоинформатика: Учеб. для студ. вузов / Е.Г.Капралов, А.В.Кошкарев, В.С.Тикунов и др.; Под ред. В.С.Тикунова. - М.: Издательский центр «Академия», 2005. - 480 с.

6. Двинских С.А., Ветровое волнение в условиях водохранилищ (на примере Камского водохранилища), автореферат, 1975г.

7. Зейлер М. Моделирование нашего мира. Руководство ESRI по проектированию баз геоданных. .- М.: Дата+. $-2001 . \neg 254 \mathrm{c.}$

8. Изучение ГИС. Создание географических информационных систем с помощью персональных компьютеров. Перевод и издание Дата+, Москва, 1995.

9. Кузнецова Л.А. Гидрология Урала на рубеже веков, тезисы доклада научно-практической конференции, Пермь, 1999г.

10. Материалы КГУ «Аналитический центр», 20032007 г.

11. Материалы ФГУ «Камводэксплуатация», 2008 г.

12. Материалы ФГУ «ТФИ по Пермской области» и ФГУ «ТФИ по КПАО» 
13. Трифонова, Т. А. Геоинформационные системы и дистанционное зондирование в экологических исследованиях : учеб. пособие для вузов / Т. А. Трифонова, Н. В. Мищенко, А. Н. Краснощеков. М. : Акад. Проект, 2005. - 352 с.

14. Химическая география вод и гидрогеохимия Пермской области. Под редакцией Максимовича Г. А. Пермь, 1967.,

15. Шитиков В.К., Розенберг Г.С., Зинченко Т.Д. Количественная гидроэкология: методы системной идентификации. - Тольятти: ИЭВБ РАН, 2003. - 463 с. 